\title{
Optimalisasi Peran Pendamping Desa terhadap Pencegahan Fraud Pemerintah Desa di Kabupaten Demak
}

\author{
Adiwijaya, Muhammad Ja'far Shodiq, Muthoharoh \\ Dept. of Accounting, Faculty of Economics, Universitas Islam Sultan Agung, \\ Semarang, Indonesia \\ *Corresponding author: \\ Jl.RayaKaligawe Km.4 Semarang Jawa Tengah \\ NomorTelepon: (024)6583584 ; (024)6582455 \\ No Fax: (024)6582455 \\ Email: provita.w@unissula.ac.id
}

Provita Wijayanti*, Nisa' Uzlifat Nasrullah, Indri Kartika, Kiryanto, Zainal Alim

$\begin{array}{llll}\text { Received: } & \text { Revised: } & \text { Accepted: } & \text { Published: } \\ 25 \text { April 2019 } & \text { 16 May 2020 } & \text { 17 May 2020 } & \text { 31 May 2020 }\end{array}$

\begin{abstract}
Abstrak
Pemerintah desa melaksanakan tugas pengelolaan dan pertanggungjawaban dana desa dengan di didukung Infrastruktur pengawasan pemerintah desa meliputi auditor inspektorat Kabupaten, badan perwakilan desa, pendamping desa, sistem pengawasan dan tata kelola pemerintah desa. Tujuan paper ini menganalisis peran pendamping pemerintah desa dan sistem pengendalian intenal terhadap pencegahan fraud. Populasi dalam kegiatan pengabdian masyarakat ini merupakan seluruh pendamping desa di Kabupaten Demak. Teknik insidental sampling digunakan dalam pengabdian ini dan diperoleh 51 orang pendamping desa di Kabupaten demak yang menjadi mitra dalam program pengabdian masyarakat oleh tim dosen akuntansi Fakultas Ekonomi Universitas Islam Sultan Agung. Data mengenai persepsi peran pendamping pemerintah desa tentang pencegahan fraud diperoleh melalui pembagian kuesioner tertutup dengan skala likert 1-5. Hasil pengujian regresi linier berganda menunjukkan bahwa pencegahan fraud dipengaruhi secara positif oleh peran pendamping pemerintah desa sedangkan sistem pengendalian internal tidak memiliki pengaruh terhadap pencegahan fraud. Hal ini menjadi rekomendasi bagi pemerintah untuk meningkatkan kualitas pendamping desa.
\end{abstract}

Kata kunci: Peran Pendamping Desa; Sistem Pengendalian Internal; Pencegahan Fraud.

\begin{abstract}
Village government carries out the task of managing and accountability of village funds supported by village government supervision infrastructure including the district inspectorate auditor, board of village representative, village assistants, supervision systems and village government governance. The purpose of this paper is to analyze the role of village government assistants and internal control system on fraud prevention. The population in this voluntary service activity was
\end{abstract}




\title{
Indonesian Journal of Community Services
}

Volume 2, No. 1, May 2020

http://jurnal.unissula.ac.id/index.php/ijocs

DOI: http://dx.doi.org/10.30659/ijocs.2.1.55-67

\begin{abstract}
all village assistants in Demak Regency. Incidental sampling technique was used in this voluntary service and 51 village assistants in Demak district were found as partners in the voluntary service program by a team of accounting lecturers at Faculty of Economics, Sultan Agung Islamic University. Data on perceptions of the role of village government assistants on fraud prevention were obtained through the distribution of closed questionnaires with a Likert scale of 1-5. The results of multiple linear regression tests indicated that fraud prevention is positively influenced by the role of village government counterparts while internal control system has no influence on fraud prevention. This becomes a recommendation for the government to improve the quality of village assistants.
\end{abstract}

Keywords: The role of village facilitators; internal control system, fraud prevention

\section{PENDAHULUAN}

Pemerintah berusaha mewujudkan pemerataan kesejahteraan masyarakat pedesaan dengan program Dana Desa. Awal dimulakannya kucuran dana desa tersebut sejak tahun 2015 dimaksudkan untuk membantu terbangunnya sarana dan prasarana di desa yang bermanfaat untuk memperlancar kegiatan perekonomian di desa. Dana desa juga dapat dimanfaatkan untuk membantu masyarakat miskin perdesaan untuk mewujudkan hunian dan lingkungan yang layak.

Fungsi dana desa diperuntukkan bagi pembangunan kesejahteraan masyarakat desa secara luas dan bersama-sama. Tidak sejalan dengan tujuan tersebut banyak oknum yang tidak bertanggungjawab dan kelompok tertentu menyalahgunakan dana desa untuk kepentingan pribadi masih sangat sering terjadi. Beberapa fakta mengenai penyelewengan dana desa telah diberitakan terjadi hampir di setiap kabupaten di Indonesia. Laporan Indonesian Corruption Watch (2018) menyebutkan jumlah kasus korupsi desa selalu meningkat $100 \%$ (seratus persen) dari tahun ke tahun. Sebagaimana dampak dari fraud dana desa yang sangat merugikan, maka upaya pencegahan fraud sangat diperlukan. Salah satu upaya pencegahan tersebut dilakukan pemerintah pusat melalui pembentukan dan penunjukan para pendamping desa. Tugas pokok pendamping desa diantaranya adalah memfasilitasi mendampingi pengelolaan keuangan desa, dan melakukan evaluasi dalam pelaksanaan pembangunan desa. Selain pendamping desa, upaya lain juga dapat dilakukan melalui penguatan system pengendalian internal pemerintah desa. Sistem pengandalian internal menyajikan procedural yang sesuai dengan kebutuhan desa sehingga memungkinkan adanya pengawasan dalam pelaksanaan setiap kegiatan pemerintah desa secara sistemik. Dua aspek ini diharapkan dapat meminimalisir kemungkinan fraud yang hendak dilakukan oleh pihak-pihak tidak bertanggung jawab.

Berdasarkan latar belakang di atas, kegiatan pengabdian masyarakat ini dilakukan untuk menjawab permasalahan desa mitra yang berkaitan dengan peran pengawas desa yang meliputi pendamping desa dan SPI terhadap pencegahan fraud dana desa. Desa mitra dalam program ini merupakan desa-desa binaan tim pengabdian masyarakat dosen akuntansi Fakultas Ekonomi Universitas Islam Sultan Agung yang tersebar di wilayah Kabupaten Demak. Hasil dari program pengabdian ini diharapkan dapat memberikan kontribusi bagi pencegahan fraud dana desa yang diawali dari daerah binaan. Paper ini 


\section{Indonesian Journal of Community Services}

Volume 2, No. 1, May 2020

http://jurnal.unissula.ac.id/index.php/ijocs

DOI: http://dx.doi.org/10.30659/ijocs.2.1.55-67

memiliki kebaruan dari analisis hasil Pengabdian menjadi artikel publikasi dengan melibatkan partisipasi pendamping desa terkait pencegahan fraud dana desa.

Menurut Legal Dictionary, fraud secara hukum adalah kecurangan yang disengaja untuk mengamankan keuntungan atau laba yang tidak adil atau melanggar hukum, atau untuk menghilangkan korban dari hak hukum. Fraud itu sendiri dapat menjadi kasus salah perdata, kejahatan yang dapat dituntut dan dipenjara oleh otoritas pemerintah, atau kasus yang tidak menyebabkan kerugian uang, hak milik atau hak hukum tetapi masih merupakan unsur dari kesalahan perdata atau pidana lainnya. Tujuan fraud dapat berupa keuntungan moneter atau keuntungan lainnya, seperti mendapatkan paspor atau dokumen perjalanan, SIM atau kualifikasi untuk hipotek melalui pemberian pernyataan palsu (Lawrence, G.M., dan Wells, 2004). Fraud merupakan masalah yang harus diperangi bagi sektor publik maupun swasta khususnya di Indonesia. Auditor internal yang kompeten dalam mengevaluasi laporan keuangan dan mampu mengefektivitaskan operasi organisasi diperlukan untuk meminimalisasi risiko fraud (Wilopo, 2006). Penguatan struktur pengendalian internal, optimalisasi aktivitas pengendalian, juga fungsi internal audit yang efektif merupakan strategi-strategi pencegahan fraud (Wuysang et al., 2016).

Program pengabdian ini untuk mengevaluasi implementasi agency dan GONE theory. Agency theory (Jensen and Meckling, 1976) dalam Sudarma \& Putra (2014) mendefinisikan tentang keterkaitan antara principal dan agen dalam mendeteksi fraud. Teori ini bertujuan untuk menyelesaikan problem dalam hubungan keagenan antara principal dan agen yang berbeda dinamakan sebagai agency problems (Kusumastuti \& Meiranto, 2012). GONE theory dijabarkan sebagai berikut: Greeds (keserakahan), Opportunity (kesempatan) melakukan fraud, Needs (kebutuhan untuk menunjang kehidupan, dan Exposure (pengungkapan) konsekuensi bagi pelaku, apabila pelaku terbukti melakukan fraud. Exposure berkaitan dengan proses pembelajaran perbuatan fraud karena dianggap sanksi yang diberikan tergolong ringan. Faktor Greeds dan Needs berkaitan dengan perilaku individu maupun kelompok organisasi untuk melakukan kecurangan (fraud) sehingga merugikan korban. Keserakahan dan kebutuhan bersifat personal dan sulit dihilangkan sehingga cenderung melanggar peraturan, sedangkan faktor Opportunity dan Exposure berkaitan dengan korban (masyarakat, instansi dan organisasi) yang merasa dirugikan karena perbuatan kecurangan (fraud). Komponen-komponen dari agency dan GONE theory yang telah disebutkan tersebut di atas dapat diminimalisir melalui adanya peran pengawas pemerintah desa dan SPI.

Fungsi pengawas pemerintah desa yang masih minim juga merupakan faktor penyebab adanya fraud dana desa. Pihak legislative pemerintah desa (BPD) yang bertugas mengawal kinerja pemerintah desa belum sepenuhnya optimal dalam menjalankan perannya. BPD seharusnya dapat berperan penting dalam mencegah korupsi dana desa di desa, termasuk mendorong masyarakat desa lainnya untuk bersama-sama mengawasi pembangunan di desa (Indonesian Corruptio Watch, 2018). Fungsi pengawasan terhadap pencegahan fraud telah banyak yang dipublikasi. Studi kualitatif (Wibisono dan Purnomo, 2017) melaporkan bahwa pengelolaan dana desa yang lemah dan kecenderungan fraud dana desa disebabkan karena pendamping desa yang kurang berperan dalam pengawasan, unsur pembinaan dan pengawasan dari pihak 
kecamatan dan juga dari pihak Tim Pengawalan Pengamanan Pemerintahan dan Pembangunan (TP4) yang lemah, minimnya partisipasi warga dalam mengawasi pelaksanaan ADD, biaya non budgeter yang tinggi, serta (SDM) pengelola dana desa dan kepala desa yang kurang cakap. Studi kualitatif yang telah dilakukan oleh (Wida, Supatmoko, dan Kurrohman, 2017) di Kabupaten Banyuwangi tepatnya di desa-desa kecamatan Rogojampi melaporkan tahap pengawasan alokasi dana desa yang sudah berjalan dengan baik dan diharapkan dapat mencegah terjadinya fraud.

$\mathrm{H}_{1}$ : Peran pengawas pemerintah desa berpengaruh positif terhadap pencegahan fraud

Penggunaan variabel SPI untuk pencegahan fraud telah banyak dilaporkan. Atmadja, Adi dan Saputra (2015) melaporkan bahwa SPI berpengaruh terhadap fraud prevention pada desa-desa di kabupaten Buleleng Bali. (Widiyarta, 2017) melaporkan bahwa pencegahan fraud dapat dipengaruhi secara positif oleh SPI.

$\mathrm{H}_{2}$ : Sistem pengendalian internal berpengaruh positif terhadap pencegahan fraud

\section{METODE}

Populasi pengabdian ini berjumlah 125 orang pendamping desa yang ditugaskan di 249 desa di Kabupaten Demak. Berdasarkan jumlah populasi tersebut melalui teknik insendental sampling diperoleh 51 orang pendamping desa yang secara sukarela bersedia berpartisipasi dalam penelitian. Pemilihan Teknik ini atas dasar kemudahan, tidak ada kriteria yang ditetapkan melainkan menurut perangkat desa yang bisa ditemui atau yang bersedia menjadi responden (Sekaran \& Bougie, 2013).

Data diperoleh dengan cara membagikan kuesioner tertutup dengan menggunakan skala likert. Pencegahan fraud merupakan variabel dependen yang direpresentasi dengan 9 pertanyaan. Sedangkan variabel peran pengawas pemerintah desa direpresentasi dengan 10 pertanyaan dan sistem pengendalian internal direpresentasi dengan 21 pertanyaan. Teknik analisis data yang digunakan meliputi analisis deskriptif statisti, analisis validitas dan reliabilitas, pengujian asumsi klasik dan regresi linier berganda. Analisis data dilakukan dengan SPSS versi 22.0.

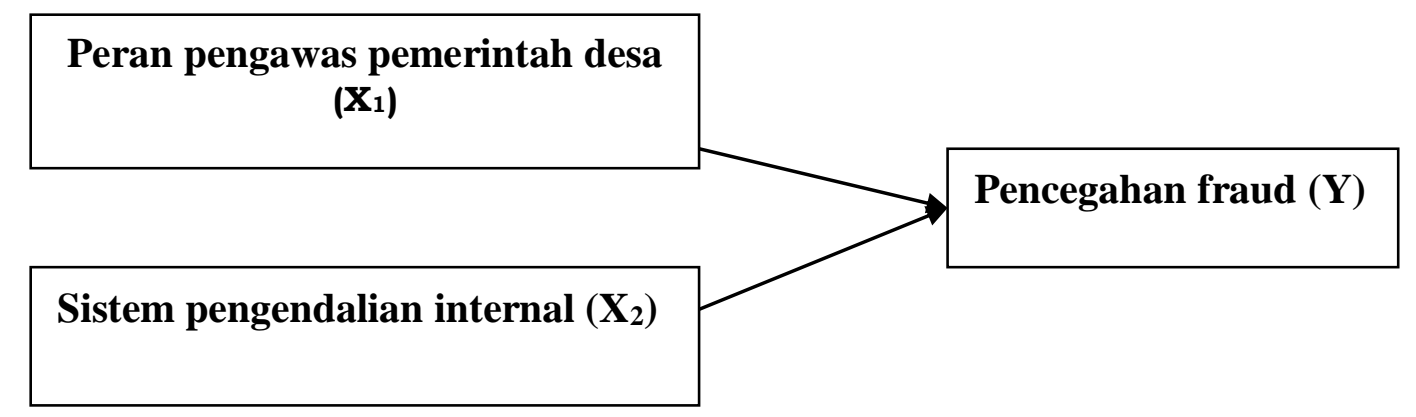

Gambar 1. Model Penelitian

Model persamaan regresi dari gambar 1:

$\mathrm{Y}=\mathrm{a}+\beta_{1} \mathrm{X}_{1}+\beta_{2} \mathrm{X}_{2}+\mathrm{e}$ 
Indonesian Journal of Community Services

Volume 2, No. 1, May 2020

http://jurnal.unissula.ac.id/index.php/ijocs

DOI: http://dx.doi.org/10.30659/ijocs.2.1.55-67

$\begin{array}{lll}\mathrm{Y} & = & \text { Pencegahan fraud } \\ \mathrm{a} & = & \text { Konstanta } \\ \beta_{1-2} & = & \text { Koefisien regresi } \mathrm{X}_{1}-\mathrm{X}_{2} \\ \mathrm{X}_{1} & = & \text { Peran pengawas pemerintah desa } \\ \mathrm{X}_{2} & = & \text { Sistem pengendalian internal } \\ \mathrm{e} & = & \text { Nilai residual/error }\end{array}$

Pengujian regresi linier berganda dilakukan untuk menganalisa apakah terdapat pengaruh antara variabel independen dengan variabel dependen secara simultan (uji F) dan secara parsial (uji t) terhadap variabel terikat. Pada uji regresi linier sederhana juga dilakukan penilaian kelayakan model dengan uji koefisien determinasi menggunakan nilai $\mathrm{R}^{2}$ adjusted.

\section{Pembahasan}

Tabel 1 menunjukkan karakteristik dari sampel pengabdian. Sebagian besar sampel adalah laki-laki (72,5\%), berumur 25-35 tahun (52,9\%), memiliki tingkat pendidikan S1 $(90,2 \%)$. Berdasarkan lama kerja, distribusi sampel relatif merata yaitu: 25,5\% lama bekerja < 3 tahun, 27,5\% untuk 3-6 tahun, sejumlah 25,4\% untuk masa kerja 7-10 tahun dan $21,6 \%>10$ tahun.

Tabel 1. Karakteristik Responden Penelitian

\begin{tabular}{ccc}
\hline Keterangan & Frekuensi & Persentase \\
\hline $\begin{array}{c}\text { Jenis } \\
\text { Kelamin }\end{array}$ & & \\
\hline Laki-laki & 37 & 72,5 \\
\hline Perempuan & 14 & 27,5 \\
\hline Usia & & \\
\hline $25-35$ th & 27 & 52,9 \\
\hline $36-46$ th & 14 & 27,5 \\
\hline $47-57$ th & 10 & 19,6 \\
\hline Masa Kerja & & \\
\hline$<3$ th & 16 & 31,4 \\
\hline $3-6$ th & 14 & 27,5 \\
\hline $7-10$ th & 10 & 19,6 \\
\hline$>10$ th & 11 & 21,6 \\
\hline Pendidikan & & \\
\hline D3 & 2 & 3,9 \\
\hline S1 & 46 & 90,2 \\
\hline S2 & 3 & 5,9 \\
\hline
\end{tabular}


Indonesian Journal of Community Services

Volume 2, No. 1, May 2020

http://jurnal.unissula.ac.id/index.php/ijocs

DOI: http://dx.doi.org/10.30659/ijocs.2.1.55-67

Hasil statistik deskriptif untuk variabel penelitian ditunjukkan pada Tabel 2 berikut.

Tabel 2. Hasil Uji Stastitik Deskripsi

\begin{tabular}{lcccc}
\hline Variabel & Min & Max & Mean & SD \\
\hline Pencegahan fraud & 28 & 45 & 39.35 & 4.078 \\
\hline $\begin{array}{l}\text { Peran pengawas } \\
\text { pemerintah desa }\end{array}$ & 25 & 50 & 38.94 & 5.097 \\
$\begin{array}{l}\text { Efektifitas pengendalian } \\
\text { internal }\end{array}$ & 46 & 105 & 77.75 & 12.309 \\
\hline
\end{tabular}

Tabel 2 menunjukkan bahwa pencegahan fraud (Y) memiliki total skor berkisar antara 28-45 dengan standar deviasi 4,078 dan rata-rata sebesar 39,35 yang jika dibagi dengan 9 indikator diperoleh nilai 4,4 yang artinya responden setuju atas pernyataan yang mewakili variabel pencegahan fraud. Variabel pengawasan dana desa $\left(\mathrm{X}_{1}\right)$ memiliki total skor berkisar antara 25-50 dengan standar deviasi 5,097 dan rata-rata sebesar 38,94 yang jika dibagi dengan 10 indikator diperoleh nilai 3,9 yang artinya responden juga setuju atas pernyataan yang mewakili variabel peran pengawas pemerintah desa. Variabel sistem pengendalian internal $\left(\mathrm{X}_{2}\right)$ memiliki total skor berkisar antara 46-105 dengan standar deviasi 12,309 dan rata-rata sebesar 77,75 yang jika dibagi dengan 21 indikator diperoleh nilai 3,7 yang artinya responden juga setuju atas pernyataan yang mewakili variabel sistem pengendalian internal.

Tabel 3 dan 4 menunjukkan hasil pengujian kualitas instrumen penelitian yang meliputi analisis validitas dan reliabillitas.

Tabel 3. Hasil Analisis Validitas

\begin{tabular}{cccc}
\hline No & Variabel & Indikator & rhitung \\
\hline \hline 1 & Pencegahan fraud $(\mathrm{Y})$ & 1 & 0,498 \\
& & 2 & 0,417 \\
& 3 & 0,622 \\
& 4 & 0,622 \\
& 5 & 0,579 \\
& & 6 & 0,644 \\
& & 7 & 0,566 \\
2 & 8 & 0,570 \\
& Peran pengawas pemerintah & 1 & 0,426 \\
& desa $\left(\mathrm{X}_{1}\right)$ & 2 & 0,293 \\
& & & 0,471
\end{tabular}




\begin{tabular}{lcc} 
& 3 & \\
& 4 & 0,721 \\
3 & 5 & 0,658 \\
Sistem pengendalian internal & 6 & 0,648 \\
$\left(\mathrm{X}_{2}\right)$ & 7 & 0,586 \\
& 8 & 0,702 \\
& 9 & 0,626 \\
& 10 & 0,505 \\
& 1 & 0,713 \\
& 2 & 0,438 \\
& 3 & 0,702 \\
& 4 & 0,541 \\
& 5 & 0,744 \\
& 6 & 0,719 \\
& 7 & 0,726 \\
& 8 & 0,750 \\
& 9 & 0,727 \\
& 10 & 0,730 \\
& 11 & 0,329 \\
12 & 0,594 \\
& 13 & 0,718 \\
& 14 & 0,411 \\
& 15 & 0,549 \\
16 & 0,505 \\
& 17 & 0,619 \\
& 18 & 0,735 \\
& 19 & 0,623 \\
& 20 & 0,627 \\
& & 0,692 \\
& & 0,332 \\
\hline
\end{tabular}

Berdasarkan tabel 3 diketahui bahwa kesembilan item variabel pencegahan fraud adalah valid karena nilai rhitung yang dihasilkan semuanya di atas rtabel (rtabel untuk $\mathrm{n}=51$, signifikansi $5 \%=0,279$ ). Semua item variabel peran pengawas pemerintah desa juga valid karena nilai rhitung yang dihasilkan semuanya juga di atas 0,279 . Semua item variabel peran pengawasan pemerintah desa juga valid karena nilai rhitung dihasilkan semuanya di atas 0,279 .

Tabel 4. Hasil Uji Reliabilitas

\begin{tabular}{llc}
\hline No & Variabel & Cronbach Alpha \\
\hline \hline 1 & Pencegahan fraud & 0,827 \\
2 & Peran Pengawas Pemerintah Desa & 0,866 \\
3 & Efektifitas pengendalian internal & 0,934 \\
\hline
\end{tabular}




\section{Indonesian Journal of Community Services}

Volume 2, No. 1, May 2020

http://jurnal.unissula.ac.id/index.php/ijocs

DOI: http://dx.doi.org/10.30659/ijocs.2.1.55-67

Nilai cronbach alpha untuk variabel pencegahan fraud, peran pengawas pemerintah desa, dan sistem pengendalian internal masing-masing sebesar 0,827;0,866; dan 0,934. Ketiganya di atas nilai cronbach alpha kritis yaitu 0,60 sehingga dapat disimpulkan terpenuhi syarat reliabelitas variabel.

Hasil pengujian asumsi klasik dari model regresi sebagai berikut:

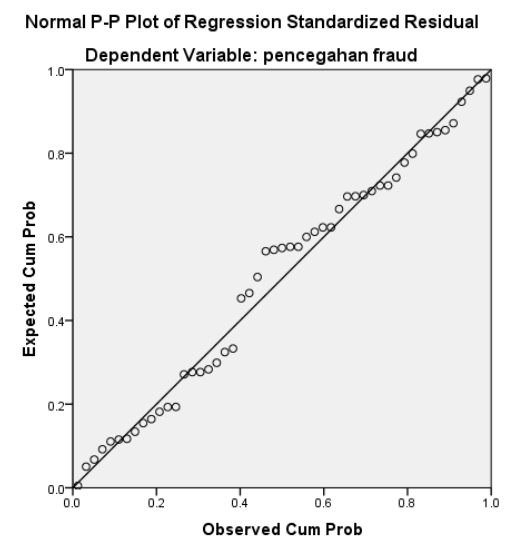

Gambar 2. Grafik Normal P-Plot

Berdasarkan gambar diatas diketahui bahwa titik-titik menyebar disekitar garis diagonal dan mengikuti arah garis diagonal menunjukkan bahwa distribusi data residual berdistribusi normal.

Tabel 5. Hasil Analisis Multikolinieritas

\begin{tabular}{llcc}
\hline \multirow{2}{*}{ No } & \multirow{2}{*}{ Variabel } & \multicolumn{2}{c}{ Collinearity Statistics } \\
\cline { 3 - 4 } & Peran pengawas pemerintah desa & 0.779 & Volerance \\
\hline \hline 1 & Efektifitas pengendalian internal & 0.779 & 1.284 \\
2 & & & 1.284 \\
\hline
\end{tabular}

Analisis multikolinieritas didapat nilai tolerance $>0,10$ dan nilai $V I F<10$ untuk masing-masing variabel bebas sehingga dapat disimpulkan variabel independen tersebut bebas multikolinearitas.

Hasil uji durbin watson diperoleh nilai $(d)$ sebesar 1,847. Pada $\mathrm{n}=51$ dan $\mathrm{k}$ (jumlah variabel bebas) $=2$ nilai du adalah 1,631. Model regresi dikatakan bebas autokorelasi ditunjukkan dengan nilai $\mathrm{du}<d<4-\mathrm{du}$. Karena 1,631 $<1,847<2,369$ maka model regresi ini dinyatakan bebas autokorelasi. 


\section{Indonesian Journal of Community Services}

Volume 2, No. 1, May 2020

http://jurnal.unissula.ac.id/index.php/ijocs

DOI: http://dx.doi.org/10.30659/ijocs.2.1.55-67

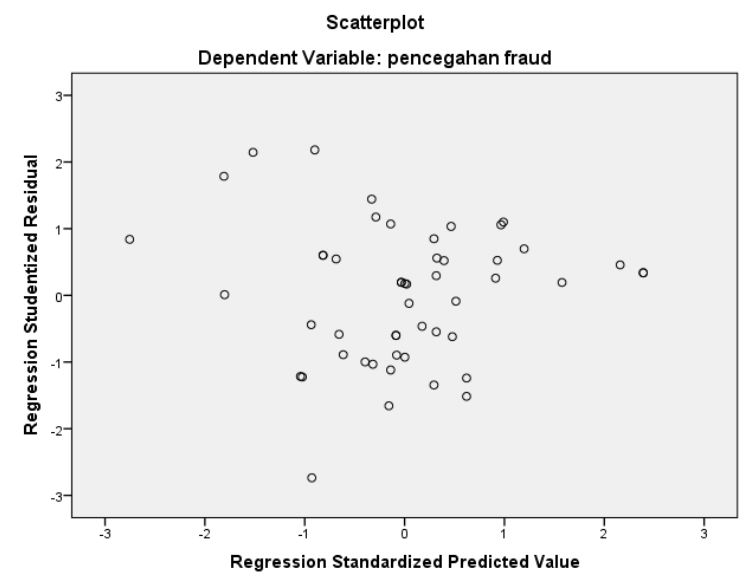

Gambar 3. Grafik Normal P-Plot

Hasil uji grafik scatter plot tampak bahwa titik-titik menyebar secara acak serta tersebar baik diatas maupun dibawah angka nol pada sumbu Y sehingga dapat menjelaskan bahwa model ini memiliki model yang baik karena merupakan model yang homoskedastisitas atau varians dari nilai residual pengamatan satu ke pengamatan yang lain tetap.

Hasil uji kelayakan model ditunjukkan sebagai berikut:

a. Hasil uji $\mathrm{F}$ diperoleh nilai sig sebesar 0,003 (sig < 0,05) menunjukkan bahwa peran pengawas pemerintah desa dan efektifitas pengendalian internal secara simultan berpengaruh terhadap pencegahan fraud.

b. Hasil uji koefisien determinasi diperoleh nilai adjusted $\mathrm{R}^{2}$ sebesar 0,180 artinya daya penjelas variabel peran pengawas pemerintah desa dan efektifitas pengendalian internal terhadap pencegahan fraud hanya sebesar 18\%, 82\% lainnya dipengaruhi oleh variabel lain di luar model ini.

Pengujian hipotesis parsial (uji t) ditunjukkan sebagai berikut:

Tabel 6. Hasil Uji Parsial

\begin{tabular}{llll}
\hline No & \multicolumn{1}{c}{ Variabel } & B & \multicolumn{1}{c}{ Sig } \\
\hline \hline 1 & Konstanta & 24,139 & 0,000 \\
2 & Peran Pengawasan Pemerintah Desa & 0,324 & 0,008 \\
3 & Efektifitas pengendalian internal & 0,033 & 0,490 \\
\hline
\end{tabular}

a. Diperoleh koefisien regresi sebesar 0,324 dengan nilai sig sebesar 0,008 ( $\operatorname{sig}<0,05)$ menunjukkan bahwa peran pengawas pemerintah desa berpengaruh positif dan signifikan terhadap pencegahan fraud.

Peran pengawas pemerintah desa terbukti berpengaruh terhadap pencegahan fraud. Hasil penelitian ini relevan dengan penelitian sebelumnya oleh (Wibisono dan 
Purnomo, 2017) bahwa pengelolaan dana desa yang lemah atau kecenderungan fraud dana desa disebabkan karena pendamping desa yang tidak berperan dengan baik, serta lemahnya pengawasan dan pembinaan dari pihak kecamatan dan juga dari pihak Tim Pengawalan Pengamanan Pemerintahan dan Pembangunan (TP4), serta minimnya partisipasi warga dalam mengawasi pelaksanaan ADD, biaya non budgeter yang tinggi, serta SDM pengelola dana desa dan kepala desa yang kurang cakap. Studi kualitatif yang telah dilakukan oleh (Wida, Supatmoko, dan Kurrohman, 2017) di Kabupaten Banyuwangi tepatnya di desa-desa kecamatan Rogojampi melaporkan tahap pengawasan ADD yang sudah berjalan dengan baik dapat mencegah fraud.

Pentingnya pengawasan bahkan telah diatur dalam Undang-Undang No. 6 tahun 2014 tentang Desa pada pasal 82 dimana warga masyarakat dijamin untuk dapat terlibat secara aktif berpartisipasi melakukan pengawasan dan pemantauan pembangunan desa. Masyarakat juga berhak memperoleh informasi tentang pelaksanaan pembangunan desa.

BPD merupakan badan yang menampung pendapat masyarakat pada pemerintah desa terkait dengan temuan hasil pengawasan, termasuk juga saran dan keluhan atas pelaksanaan pembangunan desa. Selain itu, menanggapi laporan tahunan pelaksanaan pembangunan desa dalam Musyawarah Desa adalah wujud keterlibatan masyarakat desa dalam memonitor pembangunan desa (Wibisono dan Purnomo, 2017).

Masyarakat desa juga dapat membantu melakukan pengawasan dan pemantauan pembangunan serta pengelolaan APBDesa dalam tiga tahap, yang pertama merupakan tahap perencanaan, kemudian tahap pelaksanaan, serta tahap pelaporan dan pertanggungjawaban. Melalui keikutsertaan masyarakat desa dalam pengawasan dan pemantauan pembangunan desa dan APBDesa, jika dikaitkan dengan teori agensi dan teori GONE maka keinginan untuk mementingkan diri sendiri, keserakahan, dan peluang untuk melakukan fraud dapat dicegah.

Upaya pengawasan dan pemantauan pelaksanaan pembangunan desa dan pengelolaan keuangan desa diharapkan mendorong adanya akuntabilitas pemerintah desa. Pengawasan dilakukan bukan karena adanya ketidakpercayaan masyarakat. Pengawasan dan pemantauan dilakukan justru merupakan wujud kepedulian masyarakat dalam membantu pemerintahan desa untuk terhindar dari kemungkinan kesalahan yang dapat menyeret mereka ke dalam sanksi administrasi maupun sanksi hukum.

b. Diperoleh koefisien regresi sebesar 0,033 dengan nilai sig sebesar 0,490 (sig > 0,05) menunjukkan bahwa efektifitas pengendalian internal tidak berpengaruh terhadap pencegahan fraud.

Sistem pengendalian internal tidak terbukti berpengaruh terhadap pencegahan fraud di desa-desa di Kabupaten Demak. Hasil ini tidak relevan dengan beberapa penelitian yang telah dilakukan, antara lain penelitian (Atmadja et al., 2017) yang melaporkan bahwa pencegahan fraud pada desa-desa di Kabupaten Buleleng dipengaruhi oleh sistem pengendalian internal, penelitian (Widyatama dan Novita, 2017) yang juga melaporkan pengaruh positif SPI terhadap akuntabilitas dalam pengelolaan alokasi dana desa di Kabupaten Sigi, dan penelitian (Widiyarta, 2017) yang menunjukkan bahwa pencegahan fraud pengelolaan dana desa di pemerintah desa Kabupaten Buleleng dapat dipengaruhi secara positif oleh sistem pengendalian internal. 
Indonesian Journal of Community Services

Volume 2, No. 1, May 2020

http://jurnal.unissula.ac.id/index.php/ijocs

DOI: http://dx.doi.org/10.30659/ijocs.2.1.55-67

Perbedaan hasil penelitian dapat disebabkan karena perbedaan instrumen penelitian yang digunakan. Penelitian ini menggunakan variabel sistem pengendalian internal dengan dimensi-dimensi yang meliputi lingkungan pengendalian, penilaian risiko, aktivitas pengendalian, informasi dan komunikasi serta pemantauan. Sedangkan instrumen yang digunakan untuk merepresentasi pencegahan fraud meliputi budaya kejujuran, keberadaan sanksi, evaluasi kinerja pemerintah, dan penerapan sistem.

Terdapat dua jenis pengendalian internal: pengendalian preventif dan detektif. Pengendalian preventif adalah pengendalian yang dapat membantu mencegah fraud terjadi. Contoh pengendalian preventif yang baik adalah mewajibkan pemberian tanda tangan dari pimpinan pada formulir penggantian biaya. Pemberian tanda tangan tersebut menunjukkan perlunya penggantian biaya atas sepengetahuan pihak pimpinan. Kegiatan pengendalian tersebut mencegah penggantian biaya tanpa peninjauan atau pengetahuan pimpinan. Pengendalian detektif adalah pengendalian yang dapat membantu mengungkap skema fraud. Pengendalian ini umumnya kurang populer dari pada pengendalian preventif karena pengendalian ini diketahui bekerja setelah fraud terjadi. Contoh dari fraud detektif adalah ketika seorang manajer di sebuah toko merekonsiliasi saldo kas awal dengan penjualan dan saldo kas akhir. Fraud detektif dapat membantu manajer untuk segera menemukan uang yang hilang.

Kedua jenis pengendalian internal ini juga berlaku dalam dua tahap siklus fraud yang berbeda (Ramamoorti, S. \& Dupree, 2010). Ada tahap proaktif, yang menggunakan pengendalian preventif untuk meminimalkan peluang fraud. Ada juga tahap reaktif, yang bergantung pada pengendalian detektif untuk menemukan fraud setelah itu terjadi. Setelah fraud terjadi atau defisiensi pengendalian telah ditemukan, pengendalian kompensasi dapat diterapkan untuk mengurangi efek pelaporan keuangan yang merugikan (Gramling, A. A. et al, 2010). Pengendalian kompensasi dapat menjadi pengendalian preventif atau detektif yang diterapkan pada bisnis ketika ada defisiensi pengendalian dan kerja sebagai pendukung.

Misalnya, pengendalian preventif sebelumnya yang mewajibkan tinjauan pimpinan atas penggantian biaya sebelum diproses tidak berfungsi karena manajemen tidak pernah meluangkan waktu untuk mengotorisasi penggantian sehari-hari, maka pengendalian kompensasi yang kuat akan membutuhkan tanda terima untuk dilampirkan pada penggantian formulir. Dengan cara ini orang yang bertanggung jawab atas penggantian dapat memverifikasi bahwa pengeluaran itu sah dan ada. Seperti yang terlihat dalam contoh ini, pengendalian kompensasi umumnya digunakan ketika pengendalian yang sebenarnya terlalu mahal atau memakan waktu untuk ditetapkan, tetapi mereka kurang diinginkan dari pada pengendalian preventif karena mereka biasanya terjadi pada tahap reaktif dari siklus fraud. Sistem pengendalian internal dalam penelitian ini bisa juga termasuk dalam pengendalian internal detektif dimana pengendalian internal dilakukan setelah fraud sudah terjadi.

Berkaitan dengan teori keagenan, pengendalian internal seharusnya dilakukan sejak awal dari mulai para aparat pemerintahan desa menyusun rencana anggaran penggunaan dana desa hingga hasil akhir realisasi penggunaan dana desa tersebut, sehingga implementasi sistem pengendalian internal yang dilaksanakan dalam semua tahapan tersebut dapat mencegah tindakan self interest dan menyebabkan individu untuk tidak bersikap bounded rationality serta berupaya untuk risk averse. Dikaitkan dengan teori GONE, sistem pengendalian internal pada setiap tahapan ADD akan membatasi 


\section{Indonesian Journal of Community Services}

Volume 2, No. 1, May 2020

http://jurnal.unissula.ac.id/index.php/ijocs

DOI: http://dx.doi.org/10.30659/ijocs.2.1.55-67

seseorang untuk bersifat serakah (greed), membatasi peluang bertindak curang (opportunity), tidak berani bertindak untuk memperkaya diri sendiri (needs) dan takut tindakan fraudnya diketahui sehingga mereka akan berhadapan dengan sanksi atau hukuman yang diperoleh (exposure).

\section{KESIMPULAN}

Kesimpulan hasil pengabdian ini memberikan bukti dan beberapa rekomendasi sebagai berikut :

a. Peran Pengawasan Pemerintah Desa berpengaruh positif terhadap pencegahan fraud, semakin baik Peran Pengawasan Pemerintah Desa maka semakin baik pencegahan fraud. Pencegahan fraud dana desa dapat diupayakan melalui pemberdayaan Peran Pengawasan Pemerintah Desa yang tidak hanya menjadi tugas para pendamping desa tetapi juga menjadi tugas dan tanggung jawab warga masyarakat.

b. Sistem pengendalian internal berpengaruh tidak signifikan terhadap pencegahan fraud. Penelitian selanjutnya dapat menganalisis lebih lanjut komponen Sistem pengendalian internal di pemerintah desa, yang diharapkan dapat menjadi sistem pengendalian preventif maupun detektif untuk memperkuat akuntabilitas pemerintah desa.

c. Saran untuk penelitian mendatang adalah mengupayakan pengambilan data dengan wawancara, penambahan jumlah sampel serta menyertakan variabel-variabel lain misalnya kompetensi aparat pemerintah desa dalam penyusunan laporan keuangan, infrastruktur sistem pengendalian digital, dan whistleblowing (Atmadja et al., 2017; Widiyarta, 2017).

\section{DAFTAR PUSTAKA}

Atmadja, A. T., Adi, K., \& Saputra, K. (2017). Pencegahan Fraud Dalam Pengelolaan Keuangan Desa. Jurnal Ilmiah Akuntansi Dan Bisnis, 12(1), 7-16.

Gramling, A. A. et al. (2010). Audit Partner Evaluation of Compensating Controls: A focus on design effectiveness and extent of auditor testing. Auditing. A Journal of Practice and Theory, 2(29), 175-187. Retrieved from http://aaapubs.org/doi/pdf/10.2308/aud.2010.29.2.175

Indonesian Corruption Watch. Lonjakan Korupsi di Desa (2018). Retrieved from https://antikorupsi.org/id/news/lonjakan-korupsi-di-desa

Kusumastuti, N. R., \& Meiranto, W. (2012). Analisis Faktor-faktor yang Berpengaruh terhadap Perilaku Tidak Etis sebagai Variabel Intervening. Diponegoro Journal of Accounting, l(1), 1-15.

Lawrence, G.M., dan Wells, J. T. Basic Legal Concepts (2004).

Putu Mudyasani Sudarma, I. W. P. (2014). Pengaruh Good Corporate Governance Pada Biaya Keagenan kepentingan . Herawaty ( 2008 ). E-Jurnal Akuntansi Universitas Udayana, 3,

66 || Indonesian Journal of Community Services 


\section{Indonesian Journal of Community Services}

Volume 2, No. 1, May 2020

http://jurnal.unissula.ac.id/index.php/ijocs

DOI: http://dx.doi.org/10.30659/ijocs.2.1.55-67

591-607.

Ramamoorti, S. \& Dupree, J. (2010). Continuous Monitoring Can Help Deter and Prevent Fraud. In Financial Executives (pp. 66-67).

Sekaran, U., \& Bougie, R. (2013). Research Methods for Business. In Research methods for business (p. 436).

Sudarma, M., \& Putra, I. W. (2014). Pengaruh Good Corporate Governance Pada Biaya Keagenan. E-Jurnal Akuntansi Universitas Udayana, 9(3), 591-607.

Sugiyono. (2014). Metode Penelitian Pendidikan Pendekatan Kuantitatif, Kualitatif dan R\&D. Metode Penelitian Pendidikan Pendekatan Kuantitatif, Kualitatif Dan $R \& D$. https://doi.org/10.1007/s13398-014-0173-7.2

Undang-Undang No. 6 tahun 2014 tentang Desa. (n.d.). Retrieved from www.dpr.go.id/dokjdih/document/uu/UU_2014_6.pdf

Wibisono, N., \& Purnomo, H. (2017). Mengungkap Fenomena Pengawasan Publik Terhadap Dana Desa Di Kabupaten. Jurnal AKSI (Akuntansi Dan Sistem Informasi), 2, 8-19.

Wida, S. A., Supatmoko, D., \& Kurrohman, T. (2017). Akuntabilitas Pengelolaan Alokasi Dana Desa ( ADD ) di Desa - Desa Kecamatan Rogojampi Kabupaten Banyuwangi ( The Accountability in the Management of the Village Fund Allocation in Villages at Rogojampi District, Banyuwangi Regency ), IV(2), 148-152.

Widiyarta, K. dkk. (2017). Terhadap Pencegahan Fraud Dalam Pengelolaan Dana Desa ( Studi Empiris Pada Pemerintah Desa Di Kabupaten. E-Journal S1 Ak Universitas Pendidikan Ganesha, 1 .

Widyatama, A., \& Novita, L. (2017). Pengaruh Kompetensi dan Sistem Pengendalian Internal Terhadap Akuntabilitas Pemerintah Desa dalam Mengelola Alokasi Dana Desa ( ADD ). Berkala Akuntansi Dan Keuangan Indonesia, 02(02), 1-20.

Wilopo. (2006). AnalisisFaktor-faktor yang Berpengaruh terhadap Kecenderungan Kecurangan Akuntansi: Studi pada Perusahaan Publik dan Badan Usaha Milik Negara di Indonesia. In SNA 9. Padang.

Wuysang, R. V. O., Nangoi, G., \& Pontoh, W. (2016). Analisis Penerapan Akuntansi Forensik Dan Audit Investigatif Terhadap Pencegahan Dan Pengungkapan Fraud Dalam Pengelolaan Keuangan Daerah Pada Perwakilan Bpkp Provinsi Sulawesi Utara. Journal of Accounting Forensic, 31-53. 